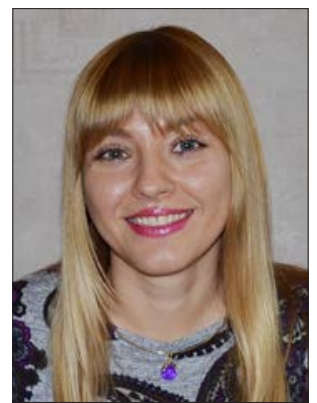

Karina V. Belokon Бєлоконь Каріна Володимирівна

УДК 66.074:66.097

\title{
INVESTIGATION OF THE PHASE COMPOSITION OF NI-AL CATALYSTS EFFECT ON THEIR PHYSICOCHEMICAL AND CATALYTIC PROPERTIES DURING THE NEUTRALIZATION OF GAS EMISSIONS INTO THE ATMOSPHERE
}

\section{ДОСЛІДЖЕННЯ ВПЛИВУ ФАЗОВОГО СКЛАДУ NІ-АL КАТАЛІЗАТОРІВ НА ÏХНІ ФІЗИКО-ХІМІЧНІ ТА КАТАЛІТИЧНІ ВЛАСТИВОСТІ ПРИ ЗНЕШКОДЖЕННІ ГАЗОВИХ ВИКИДІВ В АТМОСФЕРУ}

\author{
DOI https:// doi.org/ 10.15589/smi2020.1(13).5
}

Karina V. Belokon

Бєлоконь Каріна Володимирівна, канд. техн. наук, доц. kv.belokon@gmail.com

ORCID: 0000-0003-2000-4052

\section{Zaporizhzhia National University, Zaporizhzhia \\ Запорізький національний університет, м. Запоріжжя}

Abstract. Of the large number of environmental problems, protecting the air basin from emissions from industrial plants is one of the most complex and relevant. The most common pollutants entering atmospheric air from industrial plants are carbon monoxide (CO) and hydrocarbons $\left(\mathrm{C}_{\mathrm{m}} \mathrm{H}_{\mathrm{n}}\right)$. One of the promising directions for the neutralization of $\mathrm{CO}$ and $\mathrm{C}_{m} \mathrm{H}_{n}$ is the catalytic method using catalysts based on Ni-Al intermetallic compounds with a Raney structure.

The aim of the work was a detailed study of the phase composition and structure of intermetallic compounds of the $\mathrm{Ni}-\mathrm{Al}$ system in the oxidation of carbon monoxide and hydrocarbons and the determination of the optimal phase composition to increase their catalytic activity and physicomechanical properties.

To achieve this goal, the following research methods were used: catalytic with chromatographic analysis of the gas mixture, optical and electron microscopy, X-ray phase and micro $\mathrm{X}$-ray spectral analysis, study of the specific surface and porosity of the catalysts, mathematical processing of experimental results.

The phases $\mathrm{NiAl}_{3}, \mathrm{Ni}_{2} \mathrm{Al}_{3}$ were prepared using stoichiometric ratios of the components. Due to the different rates of leaching of aluminum from the phases $\mathrm{NiAl}_{3}$ and $\mathrm{Ni}_{2} \mathrm{Al}_{3}$, the resulting skeletal catalysts are very different in their dispersion. The greatest activity in the conversion of carbon monoxide and propane was shown by the sample of the composition $\mathrm{NiAl}_{3}$ : the conversion of the starting materials on this catalyst monotonically increases in the entire range of temperatures studied, the maximum value is reached at $\mathrm{T}=300^{\circ} \mathrm{C}$ : the conversion of $\mathrm{CO}$ is $100 \%$, and the conversion of propane is $90 \%$. The $\mathrm{Ni}_{2} \mathrm{Al}_{3}$ composition system did not exhibit noticeable catalytic activity in the oxidation of carbon monoxide and propane: the conversions of the starting materials did not exceed $15 \%$ even at a temperature of $250^{\circ} \mathrm{C}$. Thus, the use of compounds of the composition $\mathrm{Ni}_{2} \mathrm{Al}_{3}$ as catalysts for the oxidation of carbon monoxide and hydrocarbons is not advisable. The $\mathrm{NiAl}_{3}$ catalyst has a macroporous spongy structure, the size of individual pores is 30-50 microns. In the $\mathrm{Ni}_{2} \mathrm{Al}_{3}$ leachate, the pores have an elongated shape, and the maximum radius of their wide part is 15-20 microns.

Thus, the effect of the phase composition and structure of the catalyst on its physicomechanical properties and catalytic activity in the oxidation reactions of carbon monoxide and hydrocarbons was first established in the work.

The developed catalysts can be used to neutralize gas emissions during annealing of refractories, during graphitization of electrodes, in sinter and coke and chemical industries, as well as to neutralize vehicle exhaust gases.

Key words: carbon monoxide; hydrocarbons; catalytic activity; phase composition; conversion; oxidation; leaching; skeletal nickel.

Анотація. 3 великого числа проблем охорони навколишнього середовища питання захисту повітряного басейну від викидів промислових установок $є$ одним із найбільш складних і актуальних. Найбільш поширеними забруднюючими речовинами, які надходять в атмосферне повітря від промислових установок, є оксид вуглецю (СО) та вуглеводні $\left(\mathrm{C}_{\mathrm{m}} \mathrm{H}_{\mathrm{n}}\right)$. Одним із перспективних напрямів знешкодження $\mathrm{CO}$ та $\mathrm{C}_{\mathrm{m}} \mathrm{H}_{\mathrm{n}} \epsilon$ каталітичний метод із використанням каталізаторів на основі $\mathrm{Ni}-\mathrm{Al}$ інтерметалідів зі структурою Ренея. 
Метою роботи було детальне дослідження фазового складу та структури інтерметалідів системи Ni-Al у реакціях окиснення оксиду вуглецю та вуглеводнів і визначення оптимального фазового складу для підвищення їхньої каталітичної активності та фізико-механічних властивостей.

Для досягнення поставленої мети використовувалися такі методи дослідження: каталітичні із хроматографічним аналізом газової суміші, оптична й електронна мікроскопія, рентгенофазовий і мікрорентгеноспектральний аналіз, дослідження питомої поверхні та пористості каталізаторів, математична обробка результатів експериментів.

Були приготовлені фази $\mathrm{NiAl}_{3}, \mathrm{Ni}_{2} \mathrm{Al}_{3}$ при використанні стехіометричних співвідношень компонентів. Завдяки різним швидкостям вилуговування алюмінію 3 фаз $\mathrm{NiAl}_{3} \mathrm{i} \mathrm{Ni}_{2} \mathrm{Al}_{3}$ одержувані скелетні каталізатори відрізняються своєю дисперсністю. Найбільшу активність у процесі конверсії оксиду вуглецю і пропану виявив зразок сполуки $\mathrm{NiAl}_{3}$ : конверсія вихідних речовин на цьому каталізаторі монотонно зростає у всьому інтервалі досліджуваних температур, максимальне значення досягається при $\mathrm{T}=300^{\circ} \mathrm{C}$ : конверсія СО становить $100 \%$ і конверсія пропану - 90\%. Система сполуки $\mathrm{Ni}_{2} \mathrm{Al}_{3}$ не проявила помітної каталітичної активності в реакції окислення оксиду вуглецю і пропану: конверсії вихідних речовин не перевищують 15\% навіть за температури $250^{\circ} \mathrm{C}$. Отже, використання сполук $\mathrm{Ni}_{2} \mathrm{Al}_{3}$ як каталізаторів процесу окислення оксиду вуглецю та вуглеводнів не доцільно. Каталізатор з $\mathrm{NiAl}_{3}$ володіє макропористою губчастою структурою, розмір окремих пор складає 30-50 мкм. У продукті вилуговування $\mathrm{Ni}_{2} \mathrm{Al}_{3}$ пори мають витягнуту форму, а максимальний радіус їх широкої частини становить 15-20 мкм.

Отже, в роботі вперше встановлено вплив фазового складу і структури каталізатора на його фізико-механічні властивості та каталітичну активність у реакціях окислення оксиду вуглецю та вуглеводнів.

Розроблені каталізатори можуть використовуватися для знешкодження газових викидів при відпалі вогнетривів, при графітуванні електродів, в агломераційному і коксохімічному виробництвах, а також для нейтралізації вихлопних газів автотранспорту.

Ключові слова: оксид вуглецю, вуглеводні, каталітична активність, фазовий склад, конверсія, окиснення, вилуговування, скелетний нікель.

\section{References}

[1] Vinogradov, S.S., Vasilyeva, I.A. (2007). Methods and equipment for cleaning and disinfection of air emissions. Ekologiya Proizvodstva, 1, 39-43.

[2] Zeifert, B., Blasquez, J.S., Moreno, J.G., Calderon, H.A. (2008). Raney-nickel catalysts produced by mechanical alloying. Rev. Adv. Mater. Sci., 18, 632-638.

[3] Borsch, V.N., Pugacheva, Ye.V., Zhuk, S.I, Andreyev, D.Ye, Sanin, V.N., Yukhvid, V.I. (2008). Multi-metal catalysts of deep oxidation of CO and hydrocarbons. Doklady Akademii Nauk (RF), 6, 775-777.

[4] Romanova, I.V., Farbun, I.A., Khaynakov, S.A., Kirillov, S.A., Zazhigalov, V.A. (2008). Investigation of the catalytic properties of materials based on transition metal oxides and cerium. Dopovidi Natsionalnoi Akademii Nauk Ukrainy, 10, 154-159.

[5] Krylov, O.V. (1970). Catalysis by Nonmetals: Rules for Catalyst Selection. New York: Academic Press, Inc.

[6] Patent № 45154, Ukraine (2009). The catalyst for the purification of carbon monoxide and hydrocarbons.

[7] Sereda, B., Kozhemyakin, G., Savela, K., Belokon, Y., Ryzhkov, V. (2009). Investigation of the effect of the phase composition of Ni-Al alloys on the physicochemical properties of skeletal nickel catalysts. Metallurgiya, 20, $112-117$.

[8] Belokon, Y., Zherebtsov, A., Belokon, K., Fedchenok, A. (2017). The investigation of physical-mechanical properties of intermetallic Ni-Al catalyst with nanostructure. IEEE International Young Scientists Forum on Applied Physics and Engineering (YSF-2017), 299-302.

[9] Belokon, K.V., Belokon, Y.A., Kozhemyakin, G.B., Matukhno, E.V. (2016). Environmental assessment of the intermetallic catalysts utilization efficiency for deactivation of the pollutants emitted by electrode production enterprises. Scientific bulletin of National mining university, 3 (153), 87-94.

[10] Belokon, K., Belokon, Y. (2018). The study of catalysts based on intermetallic NiAl alloys. Ceramic Transactions, 262, 219-225.

Постановка проблеми. Техногенними джерелами забруднення атмосферного повітря $\mathrm{CO}$ та $\mathrm{C}_{\mathrm{m}} \mathrm{H}_{\mathrm{n}} \epsilon$ теплоелектростанції, двигуни внутрішнього згоряння, підприємства хімічної, нафтохімічної та металургійної галузей промисловості. Значні обсяги, хімічні та біологічні властивості $\mathrm{CO}$ та $\mathrm{C}_{\mathrm{m}} \mathrm{H}_{\mathrm{n}}$ в газових викидах зумовлюють підвищену екологічну небезпеку в районі об'єктів, де вони утворюються.

Одним із найбільш ефективних методів захисту атмосферного повітря від забруднення оксидом вуглецю та вуглеводнями є впровадження перспективних безвідходних ресурсо- й енергозберігаючих технологічних процесів, що дозволяють уникнути або суттєво знизити викиди цих речовин в атмосферу. Але це не завжди технологічно можливо й економічно доцільно. Тому проблеми зниження викидів, які містять $\mathrm{CO}$ та $\mathrm{C}_{\mathrm{m}} \mathrm{H}_{\mathrm{n}}$, повинні вирішуватися як шляхом удосконалення й інтенсифікації традиційних методів очищення газових викидів, так і шляхом використання нових альтернативних, екологічно й 
економічно ефективних методів. Одним із ефективних процесів знешкодження газових викидів від СО i $\mathrm{C}_{\mathrm{m}} \mathrm{H}_{\mathrm{n}} \in$ каталітичне окиснення. Посилення санітарних та екологічних норм змушує шукати нові ефективні й економічні каталізатори для знешкодження відхідних газів промислових підприємств.

Нині для проведення каталітичних процесів використовують такі благородні метали, як платина, родій і паладій. Зазвичай вони наносяться на підкладки 3 діоксиду алюмінію різними методами, які екологічно шкідливі та небезпечні [1]. Однак для багатьох каталітичних реакцій можливе використання більш дешевих матеріалів і методів їх отримання. До них можна віднести каталізатори на основі інтерметалідів системи «нікель - алюміній» зі структурою Ренея (структура Ренея утворюється внаслідок вилуговування алюмінію з інтерметаліда, в якому залишається тільки нікель, що має розгалужену структуру) [2]. При лужній обробці інтерметалідів на основі алюмінію можна отримати зразки 3d-металів із високою питомою поверхнею (кілька десятків м²/г), що становлять інтерес не тільки як самостійні каталізатори, але і як носії каталітично активних фаз. У зв'язку з цим актуальним є дослідження фазового складу $\mathrm{Ni}-\mathrm{Al}$ каталізаторів і їх процесів структуроутворення.

Аналіз останніх досліджень і публікацій. Як відомо, фізико-хімічні властивості скелетних $\mathrm{Ni}-\mathrm{Al}$ каталізаторів залежать від фазового складу вихідних сплавів. Згідно з діаграмою стану системи Ni-Al у рівноважних сплавах вдається ідентифікувати такі фази: $\mathrm{Ni}_{3} \mathrm{Al}, \mathrm{NiAl}, \mathrm{Ni}_{2} \mathrm{Al}_{3}$ i $\mathrm{NiAl}_{3}$ (рис. 1). Перші два алюмініди, що з'являються у сплавах із $60 \% \mathrm{Ni}$, внаслідок високої корозійної стійкості у розчинах лугів непридатні для приготування скелетних каталізаторів [3]. $\mathrm{NiAl}_{3}$ легко вилуговується вже на холоду. $\mathrm{Ni}_{2} \mathrm{Al}_{3}$ при 10-30 руйнується повільно, однак ки-

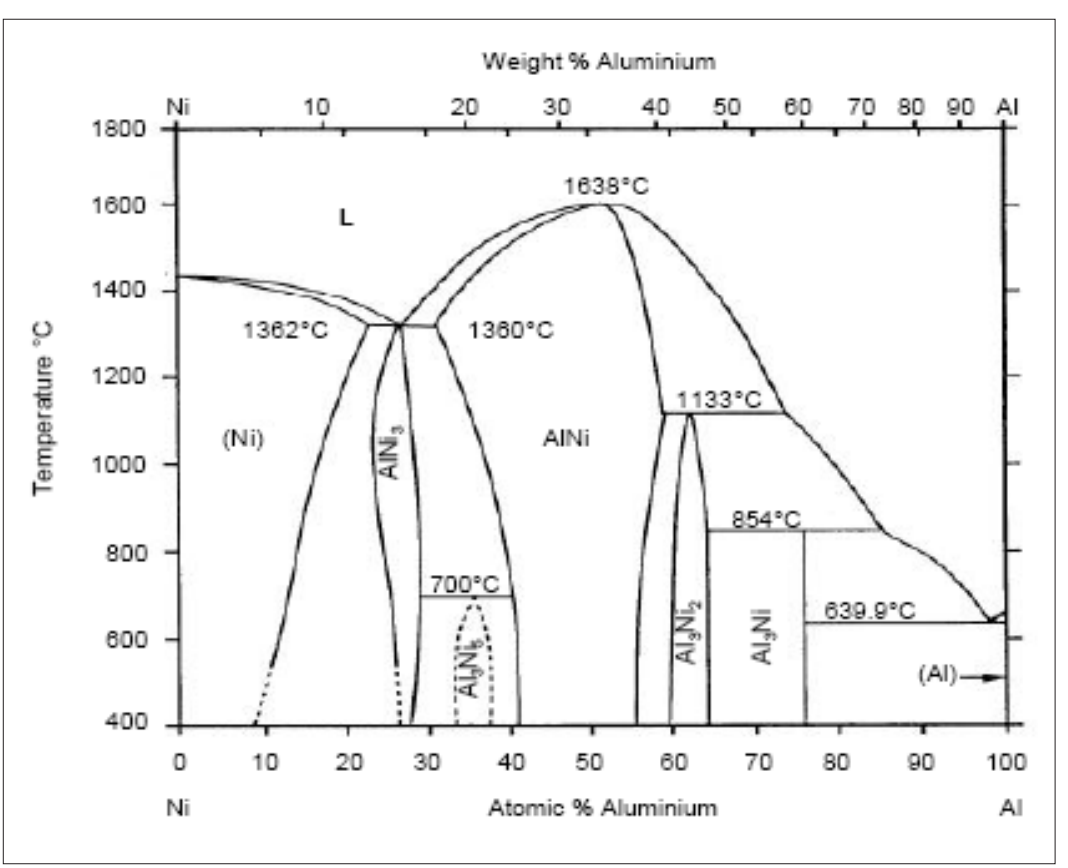

Рис. 1. Діаграма стану системи $\mathrm{Ni}-\mathrm{Al}$ плячим лугом швидко і до кінця [4]. Тому подальша наша робота була спрямована на дослідження впливу фазового складу тільки алюмінідів $\mathrm{Ni}_{2} \mathrm{Al}_{3}$ i NiAl .

Сполука $\mathrm{NiAl}_{3}$ має орторомбічну елементарну комірку, в якій знаходяться 4 атоми Ni i 12 атомів Al. $\mathrm{Ni}_{2} \mathrm{Al}_{3}$ кристалізується у тригональній сингонії. Атоми Al утворюють псевдокубічну структуру, атоми Ni займають 2/3 центрів псевдокубів, інші залишаються вакантними. Вакантні місця лежать у площинах, перпендикулярних тригональній осі. Область гомогенності $\mathrm{NiAl}_{3}$ дуже вузька, а $\mathrm{Ni}_{2} \mathrm{Al}_{3}$ - знаходиться в межах 4 ат. \% $\mathrm{Ni}$ [5].

Виокремлення не вирішених раніше частин загальної проблеми. Розробкою методів очищення шкідливих компонентів газових викидів за допомогою інтерметалідних каталізаторів займалися багато вчених: А.Б. Фасман, Н.М. Попова, Т.М. Налібаев, В.Ф. Тимофєєва, Е.А. Григорян та ін. Аналіз отриманих ними результатів свідчать про відсутність єдиного погляду на цілу низку питань: структуру продукту вилуговування, склад інтерметалідної фази каталізатора, форми добавок і т. д.

У зв'язку з цим у нашій роботі досліджувалися вихідні та вилужені сплави $\mathrm{Ni}_{2} \mathrm{Al}_{3} \mathrm{i} \mathrm{NiAl}_{3}$. 3 метою забезпечення більшої достовірності результатів були приготовлені дві серії сплавів. Особлива увага приділялася також дослідженню мікроструктури нікелю Ренея і порівнянню різних характеристик каталізаторів із $\mathrm{Ni}_{2} \mathrm{Al}_{3}$ i $\mathrm{NiAl}_{3}$.

Мета дослідження. Основні характеристики $\mathrm{Ni}-\mathrm{Al}$ каталізаторів визначаються головним чином фазовим складом і мікроструктурою, які залежать від складу самого каталізатора. Мета роботи - детально дослідити структуру $\mathrm{Ni}-\mathrm{Al}$ каталізаторів і визначити оптимальний фазовий склад, що дозволить забезпечити високий рівень каталітичної активності та фізико-механічних властивостей каталізаторів.

Методи, об'єкт та предмет дослідження. Використовувалися такі методи дослідження: каталітичні методи із хроматографічним аналізом газової суміші, оптична й електронна мікроскопія, рентгенофазовий і мікрорентгеноспектральний аналіз, дослідження питомої поверхні та пористості каталізаторів, математична обробка результатів експериментів.

Для одержання каталізаторів використовували лабораторно-промислову установку, яка складається iз таких функціональних систем: прес-обладнання, системи контролю та регулювання технологічними параметрами, системи утилізації газів. Як вихідні компоненти використовували порошки нікелю, алюмінію, кобальту, міді й оксиду марганцю. Дисперсність порошків становила 
100-150 мкм. Схема приготування шихти включала дозування, змішування, заповнення форми, пресування, термічну обробку і вилуговування. Зусилля пресування змінювали в діапазоні 25-50 кН. Скелетний каталізатор нікелю одержували шляхом вилуговування 1 г отриманого інтерметаліду при $60^{\circ} \mathrm{C} 20 \%$-им водним розчином гідроксиду натрію (100 мл) протягом 2 год. Отриманий каталізатор завантажували в установку 3 реактором проточного типу. Через установку пропускали газову суміш: $1,0 \% \mathrm{C}_{3} \mathrm{H}_{8} ; 1,5 \% \mathrm{CO} ; 5,8 \% \mathrm{O}_{2} ; 91,7 \% \mathrm{~N}_{2}, 3$ об'ємною швидкістю до 120000 год $^{-1}$ при температурі від 100 до $400-500^{\circ} \mathrm{C}$ з інтервалом $50-100^{\circ} \mathrm{C}$.

Аналіз продуктів окиснення проводився методом хроматографії за допомогою приладу «Кристал 2000 M», а також на газоаналізаторі «Паладій-3». Питома поверхня зразків визначалася за допомогою приладу СОРБІ-М. Мікроструктуру каталізаторів досліджували $з$ поперечних шліфів на мікроскопі «Neophot-21». Аналіз фазового складу здійснювали на рентгенівському дифрактометрі ДРОН-3 та на мікроаналізаторі MS-46 «Сатеса» 3 локальністю 1 мкм. Мікротвердість каталізаторів визначали на приладі ПМТ-3. Термічний аналіз досліджуваного зразка проводили на приладі марки Derivatograph Q 1050. Механічну міцність зразків із покриттям визначали за допомогою приладу УГ-20.

Основний матеріал (результати). Найважливішою стадією в отриманні каталізаторів є процес вилуговування [6]. Для зручності подальшої обробки та застосування готового каталізатора сплав піддається подрібненню. Легкість дроблення сплаву значною мірою залежить від його складу, каталітична активність сплавних каталізаторів - від повноти видалення зі сплаву алюмінію.

Від методики вилуговування залежить ступінь дисперсності частинок активного металу, а отже, i його каталітичні властивості. У табл. 1 показана залежність величини кристалів нікелю від температури вилуговування алюмінію з Ni-Al сплаву і концентрації розчину лугу [2]. Як видно з таблиці, ступінь дисперсності тим вищий, чим нижча температура вилуговування сплаву і чим менша концентрація лугу.

Враховуючи, що від концентрації лугу і температури розчинення залежить також швидкість проце- су вилуговування, оптимальним розчином прийнято вважати 20\%-вий розчин їдкого натру. Для отримання активного каталізатора вилуговування рекомендується проводити спочатку за температури $20^{\circ} \mathrm{C}$ протягом 2 год, а потім - за $115-120^{\circ} \mathrm{C}$ [3].

Спочатку процес протікає дуже бурхливо і потрібно зовнішнє охолодження. В кінці швидкість реакції зменшується, і для повного видалення алюмінію потрібно нагрівання. У міру того, як виділення водню сповільнюється, розчин зливають і додають свіжу порцію лугу. Після досягнення необхідної повноти видалення алюмінію зі сплаву каталізатор ретельно промивають водою до нейтральної реакції і, 3 огляду на його пірофорність, зберігають під водою, в абсолютному спирті або в інших інертних розчинниках. 3 огляду на незручності зберігання готових каталізаторів, сплави зазвичай витравлюють безпосередньо перед завантаженням каталізатора в промислові реактори.

Рентгенографічні дослідження, проведені в широкій області сумішей $\mathrm{Ni}-\mathrm{Al}$ сплавів, показали (рис. 2), що у всіх випадках, коли на дифрактограмах каталізаторів видно лінії ГЦК-нікелю, а їхнє становище й інтенсивність дозволяють визначити період решітки, останній становить 3,52-3,53 А́, тобто близький до характерного для масивного нікелю. Ці результати ще раз доводять помилковість висновків деяких авторів про наявність у продукту вилуговування $\mathrm{NiAl}_{3}$ ГЦК-решітки з $a=3,54-3,55 \AA$ і і про стиснення іiї до $3,48 \AA$ у каталізатора $3 \mathrm{Ni}_{2} \mathrm{Al}_{3}$ [7].

При переході від двофазної області до однофазної решітка $\mathrm{Ni}_{2} \mathrm{Al}_{3}$ стає менш спотвореною, а значення іiі параметрів і відношення $c / a$ - близькими до літературних і майже незмінними у всій області гомогенності. Збільшення концентрації нікелю в цій області значно впливає на ступінь вилуговування сплавів. Так, якщо при вилуговуванні зразків, у решітці яких атоми нікелю частково заміщені алюміні$€ \mathrm{M}$, у складі каталізаторів виявляється ГЦК-нікель, то у зразках, що відповідають стехіометричному складу $\mathrm{Ni}_{2} \mathrm{Al}_{3}$, відбувається лише спотворення скелета основної фази. Це, у свою чергу, не може не відбитися на величині поверхні та характері пористої структури каталізаторів.

Таблиця 1. Залежність величини кристалів нікелю від температури вилуговування сплаву і концентрації розчину лугу

\begin{tabular}{|c|c|c|c|}
\hline $\begin{array}{c}\text { Номер } \\
\text { каталізатора }\end{array}$ & $\begin{array}{c}\text { Концентрація } \\
\text { розчину NaOH, \% }\end{array}$ & $\begin{array}{c}\text { Температура } \\
\text { вилуговування, }{ }^{\circ} \mathbf{C}\end{array}$ & Розмір кристалів, $\AA$ \\
\hline 1 & 20 & $103-107$ & 176 \\
\hline 2 & 20 & 50 & 116 \\
\hline 3 & 20 & 20 & 103 \\
\hline 4 & 20 & 10 & 88 \\
\hline 5 & 10 & 50 & 52 \\
\hline 6 & 10 & 20 & \\
\hline
\end{tabular}



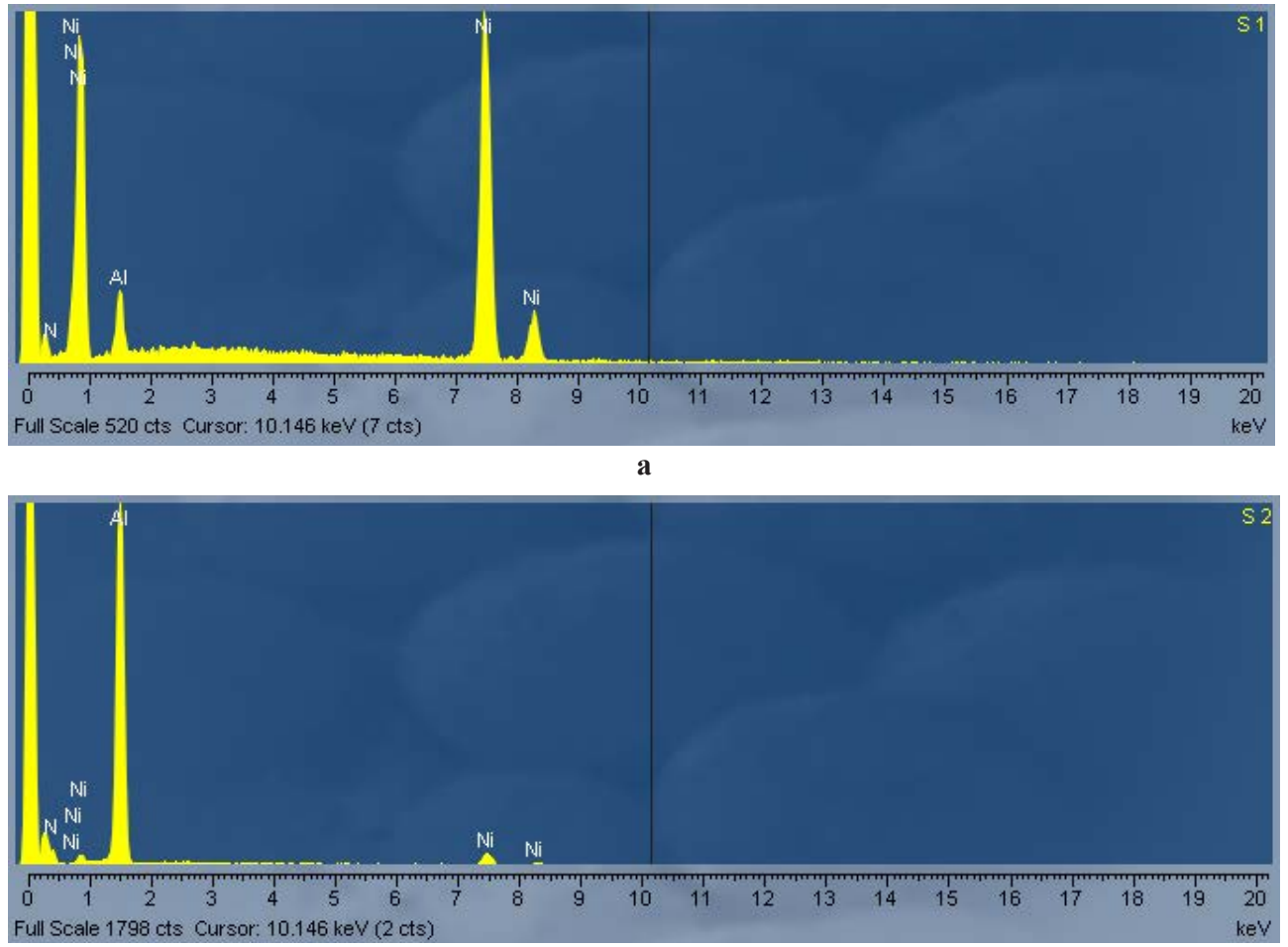

Pис. 2. Дифрактограми каталізаторів у системі $\mathrm{Ni}-\mathrm{Al}: \mathrm{a}-\mathrm{Ni}_{2} \mathrm{Al}_{3}, \sigma-\mathrm{NiAl}_{3}$

Цікаво відзначити, що питомі поверхні каталізаторів із чистих алюмінідів нікелю однакові $\left(65,5 \mathrm{~m}^{2} / \Gamma\right.$ у нікелю $\mathrm{NiAl}_{3}$ і 62,8 м²/г - у середньому для каталізаторів зі сплавів, що лежать поблизу стехіометричного складу $\mathrm{Ni}_{2} \mathrm{Al}_{3}$ ), а для більшості вилужених двофазних сплавів - майже в 1,5 рази вище (рис. 3). Відомо, що у двофазному сплаві $\mathrm{Ni}_{2} \mathrm{Al}_{3}$ (рис. 3, а) вилуговується глибше, ніж у штучній суміші його $3 \mathrm{NiAl}_{3}$ (рис. 3, б) або в однофазній області. Відбувається це внаслідок локального підвищення температури реакції за рахунок руйнування зерен $\mathrm{NiAl}_{3} \mathrm{i}$, можливо, утворення гальванічних пар $\mathrm{NiAl}_{3}-\mathrm{Ni}_{2} \mathrm{Al}_{3}$. Певну роль буде грати також подрібнення зерен фази $\mathrm{Ni}_{2} \mathrm{Al}_{3}$ порівняно з монолітом і збільшення поверхні контакту його з лугом [8].

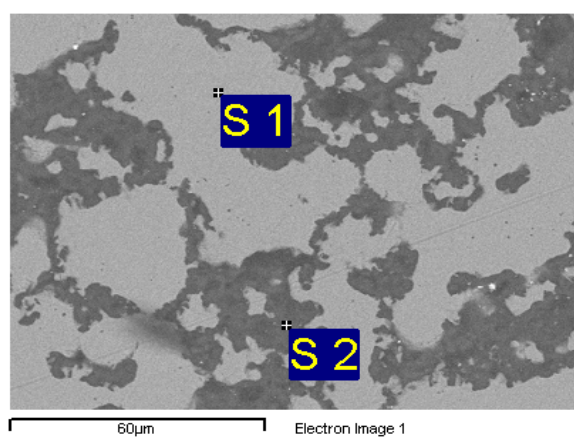

\begin{tabular}{|c|c|c|c|}
\hline № & $\mathrm{Al}$ & $\mathrm{Ni}$ & Итого \\
\hline 1 & 62,15 & 37,85 & 100,00 \\
\hline 2 & 41,84 & 58,16 & 100,00 \\
\hline
\end{tabular}

$a$
Ці фактори водночас абсолютно несуттєві при вилуговуванні $\mathrm{NiAl}_{3}$ через значно більшу швидкість корозії іiї в розчинах лугів. Величина питомої поверхні продукту вилуговування близька до характерної для каталізатора $3 \mathrm{Ni}-75 \% \mathrm{Al}$ сплаву, тоді як розміри зерен вихідної фази більше майже в 20 разів. Далі, якщо вважати, що загальна поверхня каталізаторів, приготовлених із багатофазних сплавів, адитивно складається 3 поверхонь продуктів руйнування кожної з фаз, то буде справедлива така формула:

$$
S_{\text {LET }}=c_{\varepsilon} S_{\varepsilon}+c_{\delta} S_{\delta}
$$

де $S_{b E T}$ - питома поверхня каталізаторів;

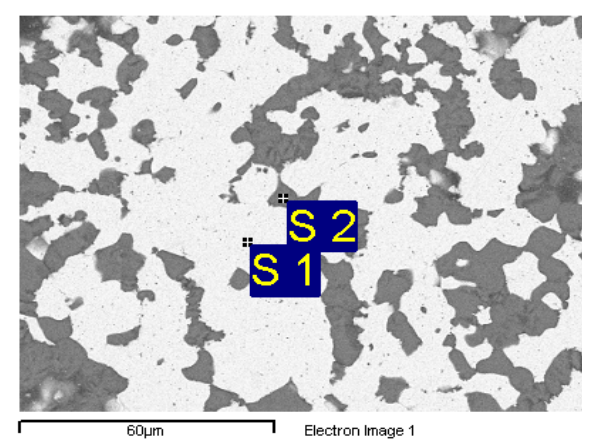

\begin{tabular}{|c|c|c|c|}
\hline № & $\mathrm{Al}$ & $\mathrm{Ni}$ & Итого \\
\hline 1 & 59,46 & 40,54 & \\
\hline 2 & 40,06 & 59,94 & 100,00 \\
\hline
\end{tabular}

б

Рис. 3. Мікроструктури і склад структурних складників $\mathrm{Ni}-\mathrm{Al}$ каталізаторів: $\mathrm{a}-\mathrm{Ni}_{2} \mathrm{Al}_{3}, \sigma-\mathrm{NiAl}_{3}$ 
$S$ i $s_{s}-$ питомі поверхні продуктів руйнування $\mathrm{NiAl}_{3}$ та $\mathrm{Ni}_{2} \mathrm{Al}_{3}$, відповідно;

$c_{\varepsilon}$ і $c_{\delta}$ - концентрації цих фаз.

Якщо вважати, що $S_{\varepsilon}$ відповідає питомій поверхні каталізатора $3 \mathrm{NiAl}_{3}$, то при відомих $c_{\varepsilon}$ і $c_{\delta}$ можна обчислити $s_{\delta}$ у двофазному сплаві. Величини $S_{\delta}$, розраховані за допомогою формули (1) для зразків із 46,2; 49,8; 51,0\% Ni, в першій серії виявилися рівними відповідно: 103; 104; $102 \mathrm{~m}^{2} / \Gamma ;$ у другій: для зразків із 52,$7 ; 54,9 ; 55,2 \% \mathrm{Ni}-99 ; 105 ; 101 \mathrm{M}^{2} /$, що в 1,5-2 рази перевищує властиву продукту вилуговування сплаву $\mathrm{Ni}_{2} \mathrm{Al}_{3}$ стехіометричного складу. Далі, якщо поверхню цього зразка, що містить 59,3\% Ni, віднести до кількості вилуженого алюмініда, то вона становитиме $108 \mathrm{~m}^{2} /$ г. Звідси випливає, що поверхня повністю зруйнованого $\mathrm{Ni}_{2} \mathrm{Al}_{3}$ перевищує $100 \mathrm{~m}^{2} /$. Таким чином, зростання питомої поверхні каталізаторів при переході від однофазних сплавів до двофазних відбувається за рахунок вкладу продукту вилуговування $\mathrm{Ni}_{2} \mathrm{Al}_{3}$. Однак це зростання поверхні відбувається переважно за рахунок утворення вузьких пір, недоступних для молекул реагуючих речовин, i співвідношення $u / u_{\delta}$, де $u$ та $u_{\delta}-$ вклади в активність продуктів вилуговування $\varepsilon$ - і $\delta$-фаз - продовжує залишатися високим [7].

Якщо допустити, що кожна фазова складова частина вносить свій внесок у сумарну активність каталізатора, то остання виражатиметься таким рівнянням:

$$
K=K_{\varepsilon} C_{\varepsilon}+K_{\delta} C_{\delta},
$$

де $K$ - питома активність каталізатора;

$K_{\varepsilon}$ та $K_{\delta}$ - вклади в активність продуктів вилуговування $\varepsilon$ - та $\delta$-фаз.

Тоді при $C \geq C_{\delta}$ вкладом $\delta$-фази в загальну активність каталізаторів можна знехтувати.

Низька активність каталізатора $3 \mathrm{Ni}_{2} \mathrm{Al}_{3}$ зумовлена насамперед невисоким ступенем вилуговування зазначеного алюмініда. Однак, навіть якщо віднести всю активність тільки до зруйнованої частини сплаву, то і в такому разі каталізатор на основі цього алюмініда буде менш активний, ніж приготований із $\mathrm{NiAl}_{3}$. Так, при стовідсотковому вилуговуванні каталізатор зі сплаву, що відповідає стехіометричному складу $\mathrm{Ni}_{2} \mathrm{Al}_{3}$, матиме питому активність в $1,8-3,4$ рази нижчу, ніж у продукту вилуговування $\mathrm{NiAl}_{3}$.

Порівняння структури цих каталізаторів показує, що розміри блоків і період кристалічної решітки ГЦКнікелю - їх активної фази - практично однакові. Основні відмінності виявляються лише в характері пористої структури, а саме: каталізатор із $\mathrm{Ni}_{2} \mathrm{Al}_{3}$ характеризується більш низькими значеннями пористості, середнього радіуса пор і присутністю значної кількості мікропор.

Також була досліджена каталітична активність інтерметалідів $\mathrm{NiAl}_{3}, \mathrm{Ni}_{2} \mathrm{Al}_{3}$ за умов процесу окиснення оксиду вуглецю і пропану $\left(\mathrm{C}_{3} \mathrm{H}_{8}\right)$ (табл. 2) [9].

Таблиця 2. Вплив температури реакції на ступінь перетворення початкових речовин у реакціях конверсії оксиду вуглецю і пропану

\begin{tabular}{|c|c|c|c|}
\hline \multirow{2}{*}{ Каталізатор } & \multirow{2}{*}{$\mathbf{T},{ }^{\circ} \mathbf{C}$} & \multicolumn{2}{|c|}{ Конверсія, \% } \\
\cline { 3 - 4 } & & $\boldsymbol{C O}$ & $\boldsymbol{C}_{3} \boldsymbol{H}_{\boldsymbol{8}}$ \\
\hline \multirow{3}{*}{$\mathrm{NiAl}_{3}$} & 150 & 5 & 0 \\
\cline { 2 - 4 } & 200 & 14 & 15 \\
\cline { 2 - 4 } & 250 & 88 & 80 \\
\cline { 2 - 4 } & 300 & 100 & 90 \\
\hline \multirow{3}{*}{$\mathrm{Ni}_{2} \mathrm{Al}_{3}$} & 200 & 3 & 0 \\
\cline { 2 - 4 } & 250 & 8 & 10 \\
\cline { 2 - 4 } & 300 & 61 & 20 \\
\hline
\end{tabular}

Із табл. 2 випливає, що найбільшу активність у процесі конверсії оксиду вуглецю і пропану проявив зразок складу $\mathrm{NiAl}_{3}$ : конверсія початкових речовин на цьому каталізаторі монотонно зростає у всьому інтервалі досліджуваних температур, максимальне значення досягається при $T=300^{\circ} \mathrm{C}$ : конверсія СО становить $100 \%$ i конверсія пропану - 90\%, що є близьким до термодинамічно можливих за цієї температури [10]. Система складу $\mathrm{Ni}_{2} \mathrm{Al}_{3}$ не виявила помітної каталітичної активності в реакціях окиснення оксиду вуглецю і пропану: конверсії початкових речовин не перевищують 15\% навіть при температурі $250^{\circ} \mathrm{C}$ (рис. $4 a$, б). Отже, використання сполук складу $\mathrm{Ni}_{2} \mathrm{Al}_{3}$ як каталізаторів процесу окиснення оксиду вуглецю і вуглеводнів недоцільне.

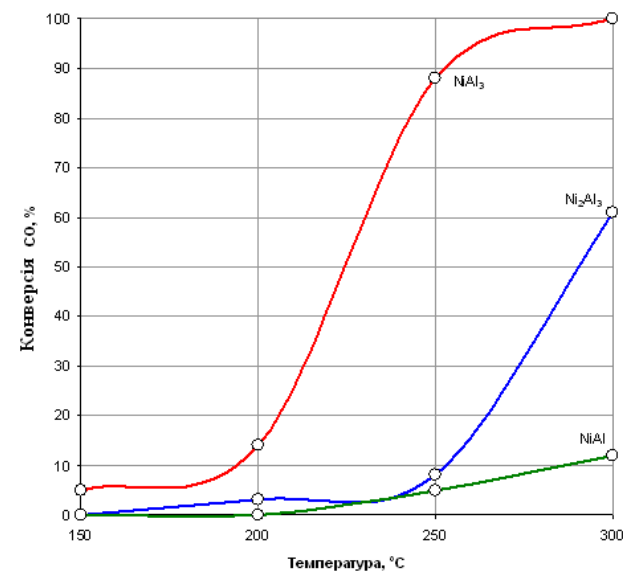

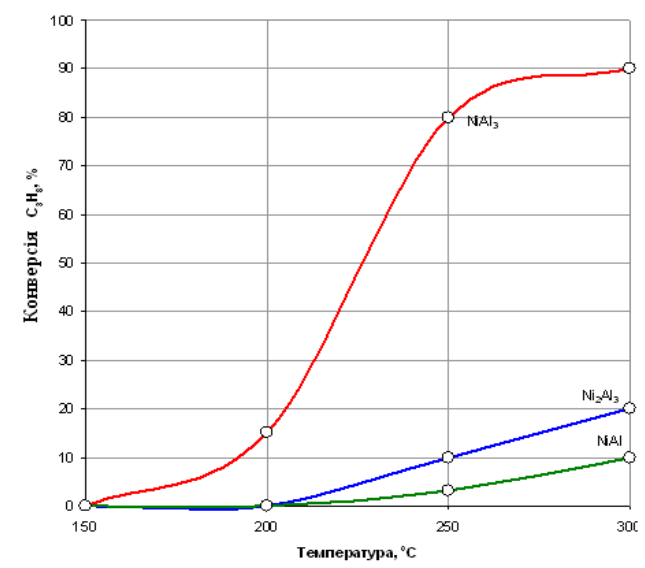

б

Рис. 4. Результати каталітичних експериментів для системи Ni-Al: $a$ - конверсія CO; б - конверсія $\mathrm{C}_{3} \mathrm{H}_{8}$ 
3 метою детальнішого вивчення морфологічних особливостей синтезованих інтерметалідів було проведено дослідження зразків методом растрової електронної мікроскопії. Відомо, що форма пор відповідає формі первинних частинок. Тоді, оскільки нікель із $\mathrm{NiAl}_{3}$ має витягнуті еліпсоїдні частинки, то і проміжки між ними повинні мати форму, близьку до циліндрової. У разі $\mathrm{Ni}_{2} \mathrm{Al}_{3}$ пори, утворені щілинами між сферами, є порожнинами з вузькими шийками.

Початковий багатофазний зразок $\mathrm{NiAl}_{3}$ має макропористу губчасту структуру, розмір окремих пор складає 30...50 мкм (рис. 5). Мікропори займають близько 1/4 порового простору. У продукті вилуговування $\mathrm{Ni}_{2} \mathrm{Al}_{3}$ пори мають витягнуту форму, а максимальний радіус їх широкої частини становить $15 . .20$ мкм. Пористість цього каталізатора, величина середнього радіуса пор і частка перехідних пор у ньому також значно нижча, ніж у приготовленому 3 $\mathrm{NiAl}_{3}$. Продукти вилуговування двофазних сплавів за характером їх пористої структури займають проміжне положення [8].

Обговорення отриманих результатів. Завдяки різним швидкостям вилуговування алюмінію з фаз $\mathrm{NiAl}_{3}, \mathrm{Ni}_{2} \mathrm{Al}_{3}$ отримувані скелетні каталізатори суттєво відрізняються своєю дисперсністю. Скелетний нікель, отриманий із фаз, утворює кубічну гранецентровану решітку, тобто процес вилуговування завжди супроводжується процесом перебудови кристалічної решітки фази, що вилуговується, з утворенням кристалічної решітки металевого нікелю, яка має велику дисперсність. Проте разом із процесом перебудови кристалічної решітки нікелю одночасно може відбуватися також вбудовування алюмінію в решітку нікелю, що призводить до зменшення постійних решітки $\left(a_{\mathrm{Ni}}=3,484 \AA\right)$. Для утворення зв'язку можуть бути використані $3 d$-орбіти нікелю і $3 p$-орбіти алюмінію. Це повинно призвести до збільшення $d$-характеристики $\mathrm{i}$, отже, до стискування кристала та збільшення каталітичної активності.

Згідно з наведеними даними скелетний нікель, отриманий iз $\mathrm{NiAl}_{3}$, володіє великою дисперс- ністю, отже, малою поверхневою інтегральною $d$-характеристикою; тому він повинен мати найбільшу поверхневу щільність хемосорбційних центрів. Проте внаслідок малої $d$-характеристики тільки невелика частина цих центрів $є$ каталітично активною. При хемосорбції водню частина хемосорбційних центрів повинна блокуватися і не брати участі у процесі каталізу. Скелетний нікель, отриманий із $\mathrm{Ni}_{2} \mathrm{Al}_{3}$, характеризується не тільки меншою дисперсністю, але і меншою величиною постійної кристалічної решітки, зумовленою хімічною неоднорідністю. Завдяки цим двом чинникам $d$-характеристика цього скелетного нікелю має бути значно більшою за таку для скелетного нікелю, отриманого з $\mathrm{NiAl}_{3}$. У цьому разі, хоча питома поверхня і поверхнева щільність хемосорбційних центрів має бути меншою, проте завдяки більшій $d$-характеристиці частка участі хемосорбційних центрів у каталітичному процесі має бути значно більшою, а кількість блокованих центрів при хемосорбції - меншою. Що ж стосується вилуженої фази $\mathrm{NiAl}$, то іiі питома поверхня і поверхнева щільність центрів хемосорбції настільки мала, що тут повинна виявлятися інша крайність, тобто ця система не повинна володіти значною каталітичною активністю.

Проведені дослідження показали, що серед синтезованих систем на основі $\mathrm{Ni}$ i $\mathrm{Al}$ активність у реакціях окиснення оксиду вуглецю і вуглеводнів проявила тільки багатофазна система $\mathrm{NiAl}_{3}$. Для збільшення каталітичної активності, підвищення резистентності каталізатора до вуглецю пропонується модифікування $\mathrm{NiAl}_{3}$ різними перехідними металами.

Висновки. Отримані експериментальні дані свідчать про те, що основні характеристики Ni-Al каталізаторів визначаються головним чином фазовим складом і мікроструктурою вихідних сплавів.

За досить повного вилуговування алюмінідів нікелю завжди утворюється ГЦК-нікель із періодом кристалічної решітки, характерним для масивного нікелю.

Активність отриманих каталізаторів змінюється антібатно концентрації нікелю в Ni-Al сплаві. Продукт вилуговування $\mathrm{NiAl}_{3}$ залежно від досліджува-

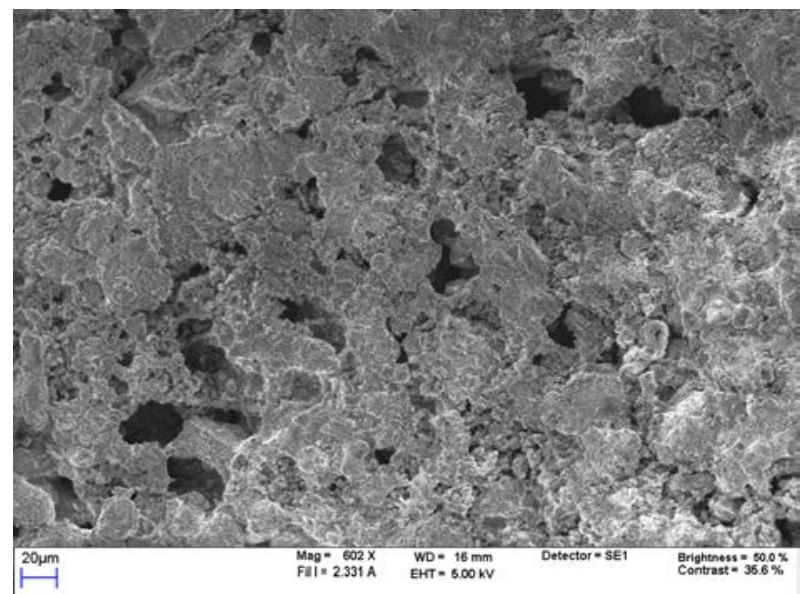

a

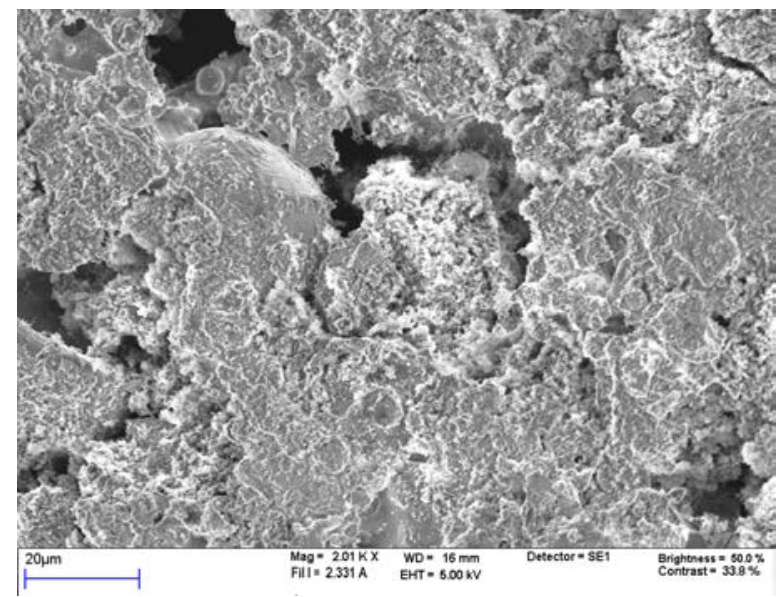

б

Рис. 5. Мікроструктура поверхні зразка $\mathrm{Ni}-\mathrm{Al}$ каталізаторів: $a-\mathrm{NiAl}_{3}, \sigma-\mathrm{Ni}_{2} \mathrm{Al}_{3}$ 
ної реакції в 3-15 разів активніший за каталізатор із $\mathrm{Ni}_{2} \mathrm{Al}_{3}$.

Найбільшу активність у процесах конверсії оксиду вуглецю і вуглеводнів виявив зразок складу $\mathrm{NiAl}_{3}$ : конверсія вихідних речовин на цьому каталізаторі монотонно зростає у всьому інтервалі досліджуваних температур, максимальне значення досягається при $\mathrm{T}=300^{\circ} \mathrm{C}$ : конверсія СО становить $100 \%$, а конверсія $\mathrm{C}_{\mathrm{m}} \mathrm{H}_{\mathrm{n}}-90 \%$, що наближається до термодинамічно максимальних за цієї температури.
Розроблений каталізатор із $\mathrm{NiAl}_{3}$ володіє макропористою губчастою структурою, розмір окремих пор становить 30-50 мкм. Мікропори займають близько 1/4 порового простору. У продукті вилуговування $\mathrm{Ni}_{2} \mathrm{Al}_{3}$ пори мають витягнуту форму, а максимальний радіус їх широкої частини становить 15-20 мкм. Пористість цього каталізатора, величина середнього радіуса пор і частка перехідних пор у ньому також значно нижчі, ніж у приготовленому $3 \mathrm{NiAl}_{3}$.

\section{Список літератури:}

[1] Виноградов С.С., Васильева И.А. Методы и оборудование для очистки и обезвреживания выбросов в атмосферу. Экология производства. 2007. № 1. С. 39-43.

[2] Zeifert, B., Blasquez, J.S., Moreno, J.G., Calderon, H.A. Raney-nickel catalysts produced by mechanical alloying. Rev. Adv. Mater. Sci. 2008. № 18. Р. 632-638.

[3] Борщ В.Н., Пугачёва Е.В., Жук С.Я., Андреев Д.Е., Санин В.Н. Многокомпонентные металлические катализаторы глубокого окисления СО и углеводородов. Доклады Академии наук. 2008. № 6. С. $775-777$.

[4] Романова И.В., Фарбун И.А., Хайнаков С.А., Кириллов С.А., Зажигалов В.А. Исследование каталитических свойств материалов на основе оксидов переходных металлов и церия. Доповіді Національної академії наук Украӥни. 2008. № 10. С. 154-159.

[5] Krylov, O.V. Catalysis by Nonmetals: Rules for Catalyst Selection. New York : Academic Press, Inc. 1970.

[6] Патент № 45154, Україна. Каталізатор для очищення оксиду вуглецю і вуглеводнів. 2009.

[7] Середа Б.П., Кожемякин Г.Б., Савела К.В., Белоконь Ю.А., Рыжков В.Г. Исследование влияния фазового состава Ni-Al сплавов на физико-химические свойства скелетных никелевых катализаторов. Металлургия. 2009. № 20. C. 112-117.

[8] Belokon, Y., Zherebtsov, A., Belokon, K., Fedchenok, A. The investigation of physical-mechanical properties of intermetallic Ni-Al catalyst with nanostructure. IEEE International Young Scientists Forum on Applied Physics and Engineering (YSF-2017). 2017. P. 299-302.

[9] Belokon, K.V., Belokon, Y.A., Kozhemyakin, G.B., Matukhno, E.V. Environmental assessment of the intermetallic catalysts utilization efficiency for deactivation of the pollutants emitted by electrode production enterprises. Scientific bulletin of National mining university. 2016. № 3 (153). P. 87-94.

[10] Belokon, K., Belokon, Y. The study of catalysts based on intermetallic NiAl alloys. Ceramic Transactions. 2018. № 262. P. 219-225.

(с) Бєлоконь К. В. Дата надходження статті до редакції: 25.06.2020 Дата затвердження статті до друку: 27.07.2020 